ELORE (ISSN 1456-3010), vol. $16-2 / 2009$.

Julkaisija: Suomen Kansantietouden Tutkijain Seura ry.

[http://www.elore.fi/arkisto/2_09/kirjallisuus_fingerroos_2_09.pdf]

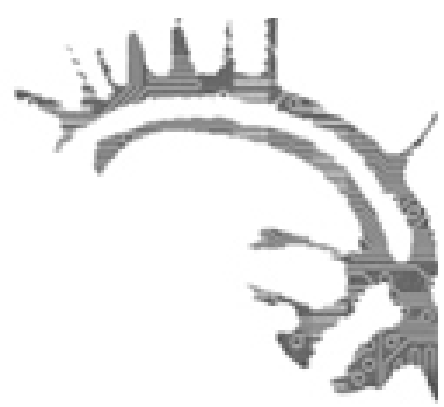

\title{
KIRJA-ARVIO:
}

\section{Painavaa tietoa maahanmuUttajanaisista}

Martikainen, Tuomas \& Tïlikainen, Marja (toim.) 2007: Maabanmunttajanaiset: kotoutuminen, perbe ja työ. Väestöntutkimuslaitoksen julkaisusarja D 46. Helsinki: Väestöliitto. 414 sivna.

\section{$\underline{\text { Outi Fingerroos }}$}

Tuomas Martikaisen ja Marja Tiilikaisen toimittama artikkelikokoelma Maahanmunttajanaiset: kotoutuminen, perbe ja työ on, aivan kuten tekijät kirjan esipuheessa toteavat, eräänlainen välitilinpäätös tähänastisesta maahanmuuttajanaisia koskevasta tutkimuksesta Suomessa. Kirja on osa Väestöliiton Työybteisöllinen tasa-arvo ja monikulttuurisuus -projektia, joka taas linkittyy Euroopan sosiaalirahaston rahoittamaan MONIKKOhankkeeseen. Kirjoittajat löytyivät Etnisten subteiden ja kansainvälisen munttoliikkeeen tutkimuksen seura ETMU ry:n sähköpostilistan kautta.

Kirja pohjaa laajalle aineistolle: pelkästään laadullisia haastatteluja kirjoittajien käytössä on ollut noin 200, ja keruut sijoittuvat Suomen lisäksi Venäjälle, Viroon, Ruotsiin, Norjaan ja Somaliaan. Mukana on myös erilaisia tilastoja, havainnointiraportteja, elämäkertakirjoituksia ja pitkäaikaiselle etnografialle perustuvia aineistoja. Tuomas Martikainen ja Marja Tiilikainen toteavatkin, että kirja luo aiempaa monipuolisemman kuvan maahanmuuttajanaisista Suomessa.

\section{KÄSITTEITÄ, TILASTOTIETOA JA AJANKOHTAISTA TUTKIMUSTA}

Kirjan aloittaa Tuomas Martikaisen ja Marja Tiilikaisen kirjoittama katsaus Maabanmunttajanaiset: käsitteet, tutkimus ja baasteet. Katsaus on erinomainen johdatus käsillä olevaan teemaan, sillä maahanmuuttotutkimukseen liittyy ryväs toisiinsa kietoutuvia käsitteitä, kuten ulkomaan kansalainen, ulkomailla syntynyt, vieraskielinen, kaksois- ja monikansalainen, uussuomalainen, maahanmuuttajataustainen, paluumuuttaja, pako- 


\section{OUtI FingerRoOS}

lainen, turvapaikanhakija, siirtolainen ja työperäinen maahanmuuttaja. Käsitteiden parissa askaroiville tutkijoille ja opiskelijoille Martikainen ja Tiilikainen tarjoavatkin kelpo työvälineet heti kokoelman alussa. Käsitteitä käsittelevä osuus on kaiken lisäksi hyvin ja sujuvasti kirjoitettu. Johdantoluku päättyy kansainvälisen ja kotimaisen tutkimuksen esittelyyn. Pidän siitä, että tutkijat nostavat esille tutkimusteemoja, jotka ovat naisiin kohdistuvassa maahanmuuttotutkimuksessa jääneet vähemmälle tai vaille huomiota. Luku päättyy artikkelien ja kirjan komposition lyhyeen esittelyyn.

Tuomas Martikaisen koostama artikkeli "Maahanmuuttajaväestön sukupuolittuneisuus, perheellistyminen ja sukupolvisuus" on luontevaa jatkoa johdantoluvulle ja erittäin kïinnostavaa luettavaa. Luku perustuu Väestöliiton Väestötutkimuskeskuksen aineistoon, jossa on yhdistetty väestö- ja perhetilastoja. Lähtökohta artikkelille on maahanmuuttotutkimukseen liittyvä tilastollinen vinouma: Suomessa tilastollinen tutkimus nimittäin on perinteisesti nojannut kolmeen keskeiseen muuttujaan, syntymämaahan, kansalaisuuteen ja kieleen. Suomen kansalaisiksi 1990-luvun jälkeen päässeet maahanmuuttajat eivät näissä tilastoissa näy - eivät myöskään maahanmuuttajien Suomessa syntyneet lapset. Artikkelissa tarkasteltavana ovatkin uudet muuttujat, Suomen maahanmuuttajaväestön rakenne, perhetilanne, toiminta ja jakaantuminen sukupolviin. Näitä muuttujia käsittelevää tutkimustekstiä kehystävät informatiiviset taulukot. Väestöliiton Väestötutkimuskeskuksen keräämän tilaston pohjalta ei ole aikaisemmin ilmestynyt tutkimustekstiä.

\section{MaAHANMUUTTAJANAISTEN KOKEMUKSIA NAISEUDESTA, ETNISYYDESTÄ JA VÄKIVALLASTA}

Kokoelmassa on yhteensä 18 artikkelia, jotka edustavat laajalti humanistista tutkimusta ja yhteiskuntatieteitä. Tekijät jakavat artikkelit kolmeksi kokonaisuudeksi, joita sisällysluetteloon tosin ei ole väliotsikoin jaoteltu. Ensimmäisessä kokonaisuudessa käsitellään maahanmuuttajanaisten kokemuksia naiseudesta, etnisyydestä ja väkivallasta. Aihepiiriin liittyviä artikkeleita on kuusi kappaletta. Minna Säävälä kirjoittaa, miten Kosovon albaaninaiset näkevät elämänsä pakolaisena, vaimona ja perheenäitinä Suomessa. Väkivallan ja naiseuteen kohdistuva häpäisyn pelko pakottivat heidätjättämään kotimaansa, mikä kokemus sävyttää elämäänsä edelleen. Tuomas Martikaisen ja Lolita Golan artikkeli Intian niemimaalta muuttaneiden naisten käsityksistä perheestä ja sukupuolirooleista avaa hieman toisenlaisen näkökulman teemaan. Valtaosa (2/3) intialaisista naisista nimittäin on tullut Suomeen perhesyistä ja vapaaehtoisesti. Heille ydinperhe on voimavara, joka luo omaankin elämään turvallisuutta ja tunteen jatkuvuudesta. Omaa perhettä verrataan suomalaisiin perheisiin, jolloin esille nostetaan kärjistäen suomalaisen perhe-elämän puutteet, jopa moraalittomuus.

Miikka Pyykkönen käsittelee artikkelissaan naisten roolia erilaisissa maahanmuuttajayhdistyksissä, joita Suomessa vuonna 2006 oli hämmästyttävän paljon, yli 700 kappaletta. Naiset ovat mukana näiden yhteisöllisessä toiminnassa aktiivisesti - ainoastaan islamilaisissa uskonnollisissa yhdistyksissä ja islamilaisten maiden etniskulttuurisissa yhdistyksissä naisia ei ole päättävissä asemissa. Aino Saarinen ja Sirkku Varjonen 
puolestaan tarkastelevat artikkeleissaan venäläistaustaisten naisten asemaa pohjoismaisissa yhteisöissä, joita usein kutsutaan naisystävällisiksi. Erityisen kiinnostava on 1990-luvun alussa Suomeen paluumuuttaneen Renatan koskettava elämäkerta. Hän on lääkäri ja äiti, joka joutui Suomeen muutettuaan tehdastyöhön ja kouluttautumaan uudelleen lääkäriksi.

Ensimmäisen jakson päättää Noora Ellosen ja Kaija Korhosen yhteisartikkeli, jossa aiheena on maahanmuuttajanaisiin kohdistunut väkivalta vuonna 2005 poliisin tietoon tulleiden rikosilmoitusten valossa. Lähtökohta artikkelissa on yhtäältä se, että suomalaisia naisia on pidetty tasa-arvoisimpina koko maailmassa, toisaalta se, että kansallisen ja kansainvälisen yhteistyön avulla on pyritty puuttumaan naisiin kohdistuvaan väkivaltaan aina 1970-luvulta alkaen. Vuonna 2005 poliisille ilmoitettiin yhteensä 1204 ulkomaalaistaustaisiin naisiin kohdistunutta väkivalta- tai uhkausrikosta. Tulos kertoo, että maahanmuuttajanaiset joutuvat suhteellisesti hieman useammin rikoksen uhriksi kuin kantasuomalaiset naiset. Lisäksi väkivaltarikokset, joita tehdään eniten, muistuttavat paljon ylipäätään naisiin kohdistuvaa väkivaltaa.

\section{Perhe-Elämä ja työ maAhanmuUttajanaisten elämässä}

Kirjan toinen ja kolmas jakso liittyvät perheen ja työelämän teemoihin. Perheeseen keskitytään neljässä artikkelissa. Heli Hyvönen on kiinnostunut Suomessa asuvien virolaisäitien transnationaaleista sosiaalisista tiloista. Hän selventää artikkelissaan keihin virolaisäidit Suomessa pitävät ylirajaisesti yhteyttä, millaisia muotoja yhteydenpidolla on ja miten näistä sosiaalisista suhteista haastatteluissa kerrotaan. Myös Pihla Siim tarkastelee artikkelissaan ylirajaisia perhesuhteita entisen Neuvostoliiton alueelta Suomeen muuttaneiden naisten perheissä. Lähestymistapa on narratiivinen. Siimin tutkimustulokset ovat samansuuntaisia kuin Hyvösenkin: Naiset elävät Suomessa moninaisten sosiaalisten suhteiden verkostossa ja arki rakentuu työn, opiskelun ja äitiyden ympärille. Yhteys Suomessa tai rajan takana asuviin, samaa kieltä puhuviin ystäviiin ja sukulaisiin on tärkeä osa omaa elämää. Minna Zechnerin ja Marja Tiilikaisen artikkeleissa avataan perheen teemaan kaksi uutta näkökulmaa. Zehner pohtii päivähoidon ja koulutuksen kysymyksiä Virosta ja Kiinasta Suomeen tulleita maahanmuuttajia haastatellen. Marja Tiilikainen puolestaan kirjoittaa Suomessa asuvien somalinaisten perhe-elämästä.

Työn teemaan paneudutaan viidessä artikkelissa. Tuula Juvosen ja Annika Forsanderin artikkeleissa yhdistävänä teemana on maahanmuuttajanaisten asema työmarkkinoilla. Kummatkin hyödyntävät artikkeleissaan tilastoja. Tutkimustulokset kertovat, että maahanmuuttajanaisten Suomessa kohtaamat ongelmat ovat hyvin samanlaisia kuin muualla maailmassa. Tasapainoilu oman taustan, perhe-elämän ja suomalaisen työkulttuurin asettamien vaatimusten välillä on heille merkittävä haaste. Venäjää äidinkielenään puhuvien naisten integroitumisen kysymykset ovat tarkastelussa Magdaleena Jaakkolan ja Anni Reuterin yhdessä kirjoittamassa analyysissa ja Pirjo Pölläsen artikkelissa. Liisa Harakkamäen artikkelissa puolestaan seurataan seitsemän maahanmuuttajanaisen asettumista suomalaiseen työelämään. Miten ja miksi he ovat 


\section{OUtI FingerRoOS}

saaneet töitä? Harakkamäen merkittävin tutkimustulos on se, että haastattelemansa naiset ovat kaikki pyrkineet mukaan työelämään ja he kokevat perheen ja työn yhdistämisen luonnollisena ja tärkeänä asiana. Työelämään integroituminen edesauttaa merkittävästi kotoutumista Suomeen, mutta prosessi on erittäin pitkä ja jokaisen naisen kohdalla erilainen.

\section{Arvio KoKonaisuUdesta}

Kirjan toimittajat Tuomas Martikainen ja Marja Tiilikainen toteavat heti kirjan esipuheessa, että kokoelma toi yhteen kotimaisia tutkijoita, jotka toisistaan tietämättä ovat töissään ja tutkimuksissaan pohtineet hyvin samanlaisia kysymyksiä. Kirja tarjoaakin edellä kuvatun kaltaisen katsauksen Suomessa tehtävään ajankohtaiseen tutkimukseen. Omille opiskelijoilleni suosittelen sen lukemista aina - etenkin kun kirja löytyy pdf-tiedostona myös internetistä osoitteesta < http://www.vaestoliitto.fi/mp/db/ file_library/x/IMG/97906/file/Maahanmuuttajanaiset_n.pdf $>$.

Tekijät toisaalta toteavat, että olisivat voineet toimittaa artikkeleita kovemmalla kädellä ja karsia teksteistä päällekkäisyyttä. Kokoelma on todella laaja, yhteensä 414 sivua tiukkaan taitettunakin. Artikkelien teemat ovat kiinnostavia, mutta kokonaisuus jää hieman hajanaiseksi. Itse jäin kaipaamaan kirjalle sisäistä työnjakoa eli teemojen mukaista väliotsikointia. Tekstejä olisi kautta linjan voinut myös tiivistää. Lisäksi kirjan alkuun tai loppuun olisi voinut liittää kirjoittajien esittelyn, sillä eri oppiaineista tulevaa kirjoittajakaartia valistunutkaan lukija tuskin tuntee.

Dosentti Outi Fingerroos työskentelee etnologian yliassistenttina Jyväskylän yliopistossa. 